\title{
MACROECONOMICS AND PROFIT SHARING FINANCING IN ISLAMIC BANKING IN INDONESIA: THE THIRD PARTIES FUND AS INTERVENING
}

\author{
Muhammad Hafizh \\ Universitas Islam Negeri Sumatera Utara, Medan \\ Jl. Williem Iskandar Pasar V Medan 20371, Sumatera Utara, Indonesia \\ Email: hafizelhabib@gmail.com
}

Nur Hidayah

Universitas Islam Negeri Syarif Hidayatullah, Jakarta

Jl. Ir. H. Djuanda No. 95, Cempaka Putih, Ciputat Timur, Tangerang Selatan, Banten 15412

Email: nurhidayah@uinjkt.ac.id

Purnama Ramadani Silalahi

Universitas Islam Negeri Sumatera Utara, Medan

Jl. Williem Iskandar Pasar V Medan 20371, Sumatera Utara, Indonesia

Email: purnamaramadani@uinsu.ac.id

\begin{abstract}
ABSTRAK
Permasalahan utama Dana Pihak Ketiga dan pembiayaan bagi hasil pada perbankan syariah di Indonesia dipengaruhi oleh faktor eksternal yang dikenal dengan istilah makroekonomi. Dana pihak ketiga sebagai variabel intervening inilah yang membedakan penelitian yang dilakukan peneliti dengan penelitian sebelumnya. Metode yang digunakan dalam penelitian ini menggunakan metode analisis jalur dengan model trimming. Hasil penelitian ini menunjukkan bahwa Ekonomi Makro secara simultan mempengaruhi Dana Pihak Ketiga. Secara parsial BI Rate, PDB, dan IHSG berpengaruh terhadap Dana Pihak Ketiga dilihat dari nilai probabilitas 0,000 $<0,05$, dimana hanya inflasi yang tidak mempengaruhi Dana Pihak Ketiga. Sedangkan secara simultan pengaruh makroekonomi terhadap bagi hasil dimana pengaruhnya secara parsial menunjukkan bahwa inflasi, BI Rate, IHSG dan Dana Pihak Ketiga berpengaruh signifikan terhadap pembiayaan bagi hasil. Dari temuan di atas, secara tidak langsung ekonomi makro melalui Dana Pihak Ketiga lebih baik untuk pembiayaan bagi hasil, karena naik turunnya Dana Pihak Ketiga berpengaruh signifikan terhadap pembiayaan bagi hasil pada perbankan syariah.
\end{abstract}

Kata kunci: bank syariah, makroekonomi, pembiayaan bagi hasil, dana pihak ketiga.

\begin{abstract}
The main problems of Third Parties Fund and profit and loss sharing financing in Islamic banking in Indonesia are influenced by external factors have known as macroeconomics. Third parties funds as an intervening variable are what distinguish research conducted by researchers from previous research. The method used in this study uses a path analysis method with a trimming model. The results of this study indicate Macroeconomics simultaneously affects Third-Parties Funds. Partially, the BI
\end{abstract}


Rate, GDP, and IHSG have an effect on Third Party Funds seen from the probability value $0.000<0.05$, where only inflation does not affect Third-Parties Funds. Meanwhile, the macroeconomy simultaneously influences the profit-sharing where the effect partially shows that inflation, the BI Rate, IHSG and Third-Parties Funds have a significant effect on profit-sharing financing. From the above findings, the macroeconomy indirectly through Third-Parties Funds is better for profit-sharing financing, because the ups and downs of Third Parties Funds significantly affect profit-sharing financing in Islamic banking.

Keywords: Islamic Banking, Macroeconomics, Profit Sharing Financing, Third Parties Fund.

\section{INTRODUCTION}

The economic growth of a country requires a pattern of regulating to the processing of economic resources that are available in a directed and integrated manner to improving the welfare of society. Economic institutions cooperate with each other in managing and mobilizing all economic potential to be optimally empowered and effective. Financial institutions, especially banking institutions have a very strategic role in driving the economy of a country. The bank is a financial institution, which functions as a financial intermediary from parties that have excess funds to those who lack funds (Sinungan, 2003).

Figure 1. Chart of Islamic Banking Growth

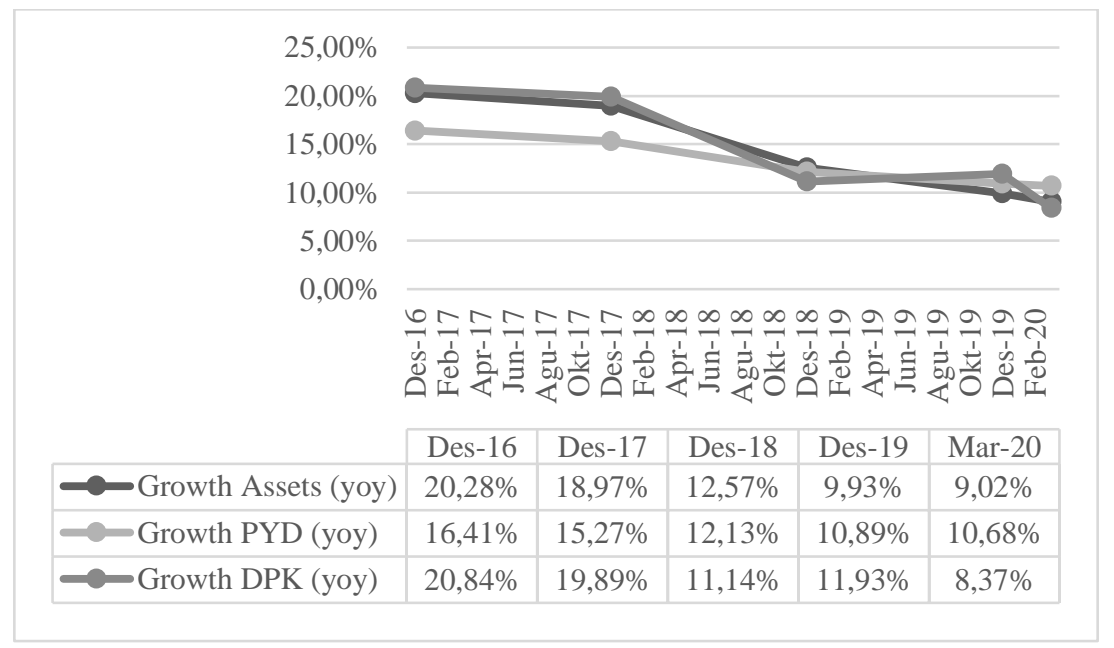

Source: www.ojk.go.id

The source of funds from the public (the "Third Parties Fund") is the most important source of funds for the operations of an Islamic bank and is a measure of the success of an Islamic bank if it is able to finance its operations from this source of funds. The importance of the source of funds from the 
third parties fund, because these funding sources indicate the level of customer confidence to place funds in Islamic banks (Kasmir, 2016: 64).

Figure 1 describes the growth of third parties fund and financing from 2016 to 2018 which continued to decline. The strengthened in 2019 and weekened again in 2020. The continued growth of third parties fund has become a problem, this is an indication that Islamic banks are not very interested in Indonesians as a reference in placing funds to be combined in Islamic banks. Even though these third parties fund will later be used by Islamic banks to be distributed back to customers through financing (HueyYeh Lin \& Koo, 2016).

Generally, there are two factors that influence the ability of banks to raise funds from the public, That is internal and external factors (Sutono \& Batista Sufa Kefi, 2013). Internal factors include; bank products, interest rate policies, service quality, office atmosphere, office location, and office reputation. External factors include; economic conditions, government activities and conditions, conditions or developments in the money and capital markets, government policies, and the regulations of Bank Indonesia (Rivai, 2007: 408-409).

Islamic banks must always maintain their ability to conduct third parties fund raising activities. The third parties fund that have been raised are then distributed into financing model. Financing that has been distributed will become a source of income for Islamic banks in addition to fee-based income (Juhro, Darsono, Syarifuddin, \& Sakti, 2018). Islamic banking has three main principles in terms of distribution, that is: trading, profit sharing or investment and leasing (Annisa \& Yaya, 2015). There is considerable critism on the practice of Islamic Bank which distribute the most financing through murabahah (trading) model and fee-based income contracts, whereas ideally Islamic banks use profit-based financing, Strengthened by Asutay's opinion (Asutay, 2012).

Generally, the factors that influence financing are divided into two, namely internal factors and external factors. Internal factors that influence financing include: third parties, profit sharing rates, and non-performing financials (NPF). External factors can be seen from macroeconomic indicators, such as: Bank Indonesia interest rates, inflation, exchange rates, Composite Stock Price Index (IHSG), and Gross Domestic Product (GDP), Bank Indonesia Certificates (Rivai, 2007).

Refer to research Sopiana (2012) which examined banking in Indonesia in 1984 to 2010 showing the effect of Macroeconomic (Interest Rates and Inflation of Certificate of Bank Indonesia) on Third Parties Fund of 0.94 (94\%). The results of the study Faridah (2013) also stated that Third Parties Fund has a positive effect on the volume of profit-based financing. Research Saekhu (2020) shows that macroeconomic indicators have a large influence, namely the Certificate of Bank Indonesia that has a positive impact while the exchange rate, inflation, the Composite Stock Price Index (IHSG) and GDP have a negative impact on the funding of Third Parties Fund of Islamic Banking in Indonesia. Meanwhile Muhammad Syahbudi's research (2017) showed that macroeconomic indicators (inflation, interest, exchange 
rates and GDP) of $97.0 \%$ had an impact on the financing of Islamic Banking in 2010-2016.

Likewise, research Cahyono (2009) showed that macroeconomic indicators have an influence on Third Parties Fund and Financing at Bank Syariah Mandiri in the 2003-2008 period. A stable macroeconomy will increase aggregate production activities so as to obtain greater income. The income will be allocated for savings. This will affect the third Parties Fund of the Mandiri Islamic bank. From the financing side, the increase in production will increase working capital and investment funds. This of course will increase the financing channeled by independent Islamic banks (Cahyono, 2009).

Islamic banking in Indonesia is experiencing serious problems, namely a decrease in third Parties Fund and a low portion of financing. The various studies conducted have resulted in various studies. Many factors cause this to happen both internally and externally. For this reason, this study will analyze the effect of macroeconomic. Third parties funds as an intervening variable are the differentiators of research conducted by researchers with previous research. Third parties funds become an intervening variable because third Parties Fund have the largest contribution from several sources of funds so that it will affect its ability to channel financing (Kasmir, 2010). According to Kuncoro, third Parties Fund account for $80 \%-90 \%$ of all funds managed by banks (Kuncoro, 2002).

\section{LITERATURE REVIEW}

\subsection{INFLATION}

Regarding inflation theory, (Karim, 2017:135) states that "in general inflation means an increase in the general level of prices of goods / commodities and services over a certain period of time or a continuous decline in the value of money. Inflation can be considered a monetary phenomenon due to a decrease in the value of the monetary calculation unit of a commodity. Inflation is the tendency for prices to increase continuously ". Thus, an increase in just one or two types of goods and cannot be called the price of other goods cannot be called inflation (Kay, 2015).

Inflation is an economic phenomenon that is always interesting to discuss, especially related to its broad impact on aggregate macroeconomic, such as economic growth, external balance, competitiveness, interest rates, and even income distribution. Inflation also plays a role in influencing the mobilization of funds through formal financial institutions (Huda, 2009).

\subsection{BANK INDONESIA RATE}

Bank Indonesia Rate is a policy interest rate that reflects the monetary policy determined by Bank Indonesia and announced to the public. Bank Indonesia is strengthening the monetary operation framework by implementing a new benchmark interest rate or policy rate, namely the BI 7-Day (Reverse) Repo 
Rate. The BI 7-day (Reverse) Repo Rate instrument is used as the new policy rate because it can quickly influence the money market, banking and real sectors (Bank Indonesia, 2018a). The operational targets for monetary policy are reflected in developments in the Interbank Money Market interest rates.

Figure 2. Chart of Inflation 2013-2018

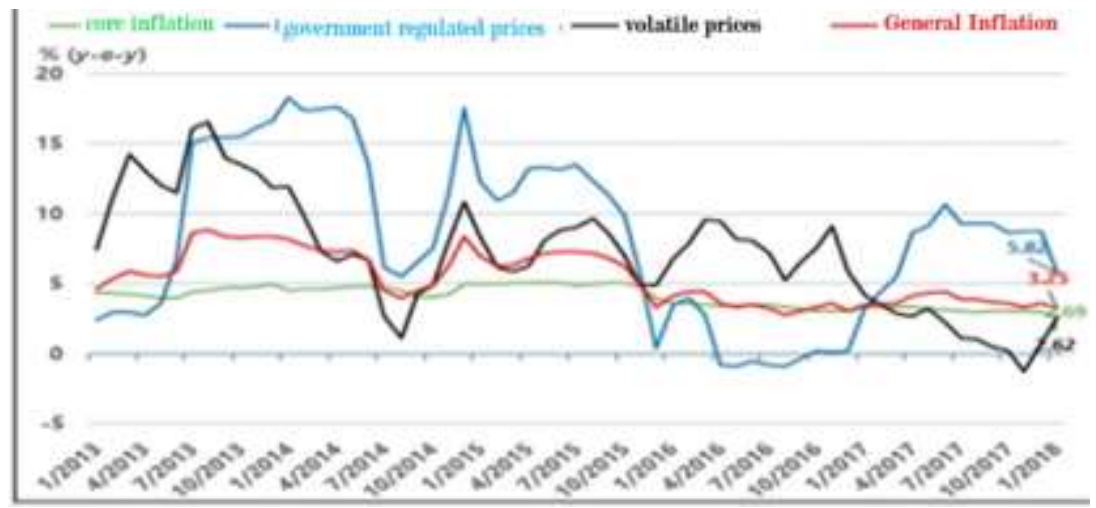

Source: BPS and CEIC (proceed by author, 2020)

The Interbank Money Market is expected to follow developments in bank deposit and loan interest rates. With other economic factors, Bank Indonesia will generally raise the BI Rate if future inflation is expected to exceed the target set (Bank Indonesia, 2018b). The determination of the monetary policy stance is carried out every month through the mechanism of the monthly Board of Governors' Meeting with monthly material coverage (Syafi'i, 2017).

Figure 3. Chart of Bank Indonesia Rate

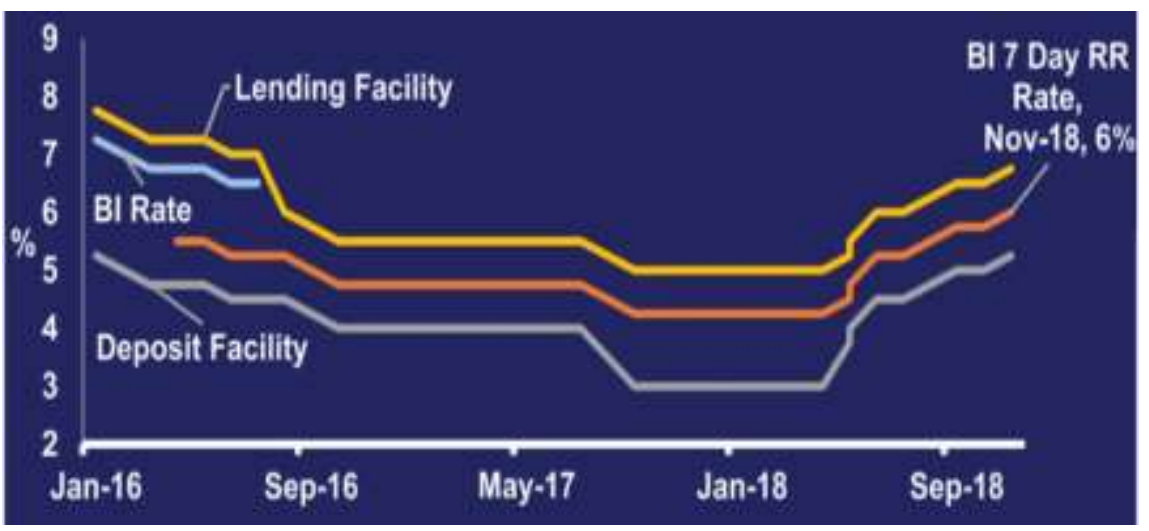

Source: Core, Economy Outlook 2019 


\subsection{REAL GDP (GROSS DOMESTIC PRODUCT)}

Real GDP is the value of goods and services measured using constant prices (regardless the inflation). Real GDP shows what will happen to expenditure on output if the amount changes but the price does not (Mankiw, 2018: 17)

\subsection{COMPOSITE STOCK PRICE INDEX (CSPI)/IHSG}

CSPI (Composite Stock Price Index) or often called IHSG is one of the stock market indices used by the Indonesia Stock Exchange as an indicator of stock market trend movements, which describes market conditions at a time, whether active or lethargic (Martalena \& Malinda, 2011). This index includes price movements of all common shares and preferred shares listed on the Indonesia Stock Exchange (Saekhu, 2017).

\subsection{THIRD PARTIES FUND}

Third parties fund (Y) is customer deposits in the form of savings, current accounts and deposits based on Islamic principles in rupiah and foreign currency raised by Islamic banks at certain times, expressed in billions of rupiah (Andraeny, 2011).

\subsection{PROFIT SHARING FINANCING}

Profit Sharing Financing $(Z)$ is the provision of funds or claims equivalent to that in the form of profit sharing transactions in the form of mudharabah and musyarakah based on an agreement or contract between an Islamic Bank and / or Islamic Business Unit and other parties that require parties to be financed and / or given with funds facility to return the funds after a certain period of time with a profit sharing system (Law No. 21 of 2008).

\section{METHODS}

This research uses descriptive quantitative method. Empirical analysis in this study used monthly time series data from January 2014 to December 2018. The population in this study were all Islamic banks in Indonesia, namely 202 banks. consisting of 14 Islamic commercial banks, 20 Islamic business units of conventional bank, 168 BPRS. While the sample is a portion of the population studied (Supriadi, 2014). The sample of this research is 14 Islamic commercial banks, 20 Islamic business units. The sampling technique uses purposive sampling, with the following criteria: Complete data on third Parties Fund and financing for the last 5 years published by Islamic Banking Statistics (SPS OJK) and Indonesian Financial Economic Statistics (SEKI).

The Data Collection Method uses publication Secondary Data obtained through Bank Indonesia, Financial Services Authority - Islamic Banking statistics, and Indonesian Central Agency on Statistics as well as Reference sources from books, journals, and websites. Using the Path Analysis method, where previously a descriptive statistical variable was 
conducted as well as the classic assumption test, namely multicollinearity, heteroscedasticity and autocorrelation and normality (Heryanto \& Wibowo, 2018; Supriadi, 2014).

The Operational Variable definition consists of 3, That is:

Exogenous Variables : Inflation, Bank Indonesia (BI) Rate, GDP, Composite Stock Price Index (IHSG)

Endogenous Variables : Profit Sharing Financing.

Intervening Variable : Third Parties Fund follows:

The panel data regression equation model used in this study shall be as

Substructure 1:

$$
Y=\operatorname{pyx}_{1} X_{1}+\operatorname{pyx}_{2} X_{2}+\operatorname{pyx}_{3} X_{3}+\operatorname{pyx}_{4} X_{4}+\varepsilon_{1}
$$

Substructure 2:

$$
Z=\operatorname{pzX}_{1} X_{1}+p_{2 x_{2}} X_{2}+p x_{3} X_{3}+p x_{4} X_{4}+p z y Y+\varepsilon_{2}
$$

\section{RESULT DAN DISCUSSION}

\subsection{DESCRIPTIVE STATISTICS OF RESEARCH VARIABLES}

Based on the results of the statistical description analysis, the following table 1 shows the characteristics of the samples used in this study including: the number of samples $(\mathrm{N})$, the average sample (mean), the maximum value, the minimum value and the standard deviation $(\sigma)$ for each variable.

Table 1. Descriptive Analysis

\begin{tabular}{lrrrrrr}
\hline & Inflation & $\begin{array}{c}\text { BI- } \\
\text { Rate }\end{array}$ & GDP & IHSG & $\begin{array}{c}\text { Third } \\
\text { Parties } \\
\text { Fund }\end{array}$ & $\begin{array}{c}\text { Profit } \\
\text { Sharing } \\
\text { Financing }\end{array}$ \\
\hline Mean & .049 & .061 & 927.27 & 4931 & 210932 & 23160 \\
\hline Maximum & .087 & .077 & 1315.52 & 6606 & 371828 & 145507 \\
\hline Minimum & .027 & .042 & 602.82 & 3470 & 75085 & 68584 \\
\hline Std. Dev. & .016 & .011 & 1989896 & 778 & 82387 & 33387 \\
\hline Observations & 96 & 96 & 96 & 96 & 96 & 96 \\
\hline \multicolumn{7}{c}{ Source: Data Processed, 2020 }
\end{tabular}

4.2 TEST RESULTS OF MACROECONOMICS SUBSTRUCTURE 1 AGAINST THIRD PARTIES FUND (Y)

\subsubsection{Simultaneous Testing (F Test)}

Table 2. F- Test Result

\begin{tabular}{crrrrr}
\hline Model & $\begin{array}{c}\text { Sum of } \\
\text { Squares }\end{array}$ & Df & $\begin{array}{c}\text { Mean } \\
\text { Square }\end{array}$ & F & Sig. \\
\hline 1 Regression & 2.786 & 4 & .697 & 521.205 & $.000^{\mathrm{a}}$ \\
\hline
\end{tabular}




\begin{tabular}{lrrcrc}
\hline Model & $\begin{array}{c}\text { Sum of } \\
\text { Squares }\end{array}$ & Df & $\begin{array}{c}\text { Mean } \\
\text { Square }\end{array}$ & F & Sig. \\
\hline Residual & .073 & 55 & .001 & & \\
\hline Total & 2.860 & 59 & & & \\
\hline
\end{tabular}

a. Predictors: (Constant), IHSG, GDP, BI Rate, Inflation

b. Dependent Variable: Third Parties Fund

Table 2 shows that the Inflation, BI Rate, GDP and IHSG simultaneously affect Third Parties Funds in Islamic banking in Indonesia.

\subsubsection{Partial Testing (T-Test)}

Table 3. T-Test Result

\begin{tabular}{lrrrrr}
\hline \multirow{2}{*}{ Model } & \multicolumn{2}{c}{$\begin{array}{l}\text { Unstandardized } \\
\text { Coefficients }\end{array}$} & $\begin{array}{l}\text { Standardized } \\
\text { Coefficients }\end{array}$ & \\
\cline { 2 - 6 } & \multicolumn{1}{c}{$\mathrm{B}$} & Std. Error & \multicolumn{1}{c}{ Beta } & \multicolumn{1}{c}{$\mathrm{s}$} & \multicolumn{1}{c}{ sig } \\
\hline Constant) & -21.012 & 2.526 & & -8.319 & .000 \\
\hline Inflasi & .018 & .025 & .028 & .719 & .475 \\
\hline BI Rate & -.084 & .039 & -.088 & -2.143 & .037 \\
\hline GDP & 1.289 & .071 & .779 & 18.149 & .000 \\
\hline IHSG & .405 & .074 & .198 & 5.482 & .000 \\
\hline
\end{tabular}

a. Dependent Variable: Third Parties Fund

Table 3 shows that the Inflation has no partial effect. Meanwhile, GDP and IHSG partially have a positive effect on third parties fund and the BI Rate has a negative effect on third parties funds.

4.2.3. Determination Test

Table 4. $\mathrm{R}^{2}$ Test Result

\begin{tabular}{|c|c|c|c|c|}
\hline Model & $\mathrm{R}$ & R Square & $\begin{array}{l}\text { Adjusted R } \\
\text { Square }\end{array}$ & $\begin{array}{l}\text { Std. Error of the } \\
\text { Estimate }\end{array}$ \\
\hline 1 & $.987^{\mathrm{a}}$ & .974 & .972 & .03656 \\
\hline \multicolumn{5}{|c|}{ a. Predictors: (Constant), IHSG, GDP, BI Rate, Inflation } \\
\hline \multicolumn{5}{|c|}{ b. Dependent Variable: Third Parties Fund } \\
\hline
\end{tabular}

Table 4 shows that the Inflation, BI Rate, GDP and IHSG are able to explain the Third Parties Funds variable by $97.2 \%$. 


\subsection{TEST RESULT OF MACROECONOMICS SUBSTRUCTURE 2 AGAINST PROFIT SHARING FINANCING $(\mathrm{Z})$}

\subsubsection{Simultaneous testing (F Test)}

Table 5. F Test Result

\begin{tabular}{lrrrrrr}
\hline Model & $\begin{array}{r}\text { Sum of } \\
\text { Squares }\end{array}$ & Df & Mean Square & F & Sig. \\
\hline 1 & Regression & 4.839 & 4 & 1.210 & $1.750 \mathrm{E} 3$ & $.000^{\mathrm{a}}$ \\
\cline { 2 - 7 } & Residual & .038 & 55 & .001 & & \\
\cline { 2 - 6 } Total & 4.877 & 59 & & & \\
\hline
\end{tabular}

a. Predictors: (Constant), Third Parties Fund, IHSG, GDP, BI Rate, Inflation

b. Dependent Variable: Profit Sharing Financing

Table 5 shows that the Third Parties Fund, IHSG, GDP, BI Rate, Inflation simultaneously affect Profit Sharing Financing in Islamic banking in Indonesia.

\subsubsection{Partial testing (T-Test)}

Table 6. Test Result of t substructure 2

\begin{tabular}{|c|c|c|c|c|c|c|}
\hline & \multirow{2}{*}{ Model } & \multicolumn{2}{|c|}{$\begin{array}{c}\text { Unstandardized } \\
\text { Coefficients }\end{array}$} & \multirow{2}{*}{$\begin{array}{c}\begin{array}{c}\text { Standardized } \\
\text { Coefficients }\end{array} \\
\text { Beta }\end{array}$} & \multirow{2}{*}{$\mathrm{t}$} & \multirow{2}{*}{ Sig. } \\
\hline & & B & $\begin{array}{l}\text { Std. } \\
\text { Error }\end{array}$ & & & \\
\hline \multirow[t]{5}{*}{1} & (Constant) & -14.138 & .951 & & -14.866 & .000 \\
\hline & Inflasi & -.052 & .017 & -.062 & -3.006 & .004 \\
\hline & BI Rate & .172 & .029 & .138 & 5.968 & .000 \\
\hline & IHSG & -.146 & .060 & -.054 & -2.444 & .018 \\
\hline & $\begin{array}{l}\text { Third } \\
\text { Parties } \\
\text { Fund }\end{array}$ & 1.440 & .037 & 1.103 & 39.265 & .000 \\
\hline
\end{tabular}

a. Dependent Variable: Profit Sharing Financing

Table 6 shows that the Inflation and IHSG has a negative effect on profit sharing financing. Meanwhile, BI-Rate and third parties funds has a positive effect on profit sharing financing

\subsubsection{Determination Test}

Table 7. Test Result of $\mathrm{R}^{2}$

\begin{tabular}{lccrr}
\hline Model & $\mathrm{R}$ & R Square & $\begin{array}{c}\text { Adjusted R } \\
\text { Square }\end{array}$ & $\begin{array}{c}\text { Std. Error of the } \\
\text { Estimate }\end{array}$ \\
\hline 1 & $.996^{\mathrm{a}}$ & .992 & .992 & .02629 \\
\hline a. Predictors: (Constant), Third Parties Fund, IHSG, GDP, BI Rate, Inflation \\
\hline b. Dependent Variable: Profit Sharing Financing \\
\hline The results of the path coefficients in substructures I and II that have \\
been done by trimming are transformed into structural equations, namely:
\end{tabular}




$$
\begin{aligned}
& Y=\operatorname{pyx}_{1} X_{1}+\operatorname{pyx}_{2} X_{2}+\operatorname{pyx}_{3} X_{3}+\operatorname{pyx}_{4} X_{4}+\varepsilon_{1} \\
& Y=0.028 X 1+(-0.088) X 2+0.779 X 3+0.198 X 4+0,161 \\
& Z=\operatorname{pzX}_{1} X_{1}+\operatorname{pzX}_{2} X_{2}+\operatorname{pzX}_{3} X_{3}+\operatorname{pzX}_{4} X_{4}+p z y+\varepsilon_{2} \\
& Z=-0.062 X 1+0.138 X 2+(-0.054) X 4+1,103 Y+0,082
\end{aligned}
$$

Figure 7. Complete Path Diagram After Trimming

\begin{tabular}{|c|c|c|c|c|c|}
\hline \multirow{2}{*}{ Model } & \multirow{2}{*}{$\begin{array}{c}\text { Path } \\
\text { Coefficients }\end{array}$} & \multicolumn{3}{|c|}{ Influence } & \multirow{2}{*}{ Notes } \\
\hline & & $\mathrm{T}$ & Sig & $\mathrm{R}^{2}$ & \\
\hline \multicolumn{6}{|c|}{ Substructure $1(\mathrm{X} 1, \mathrm{X} 2, \mathrm{X} 3, \mathrm{X} 4$ to $\mathrm{Y})$} \\
\hline $\mathrm{X} 1 \rightarrow \mathrm{Y}$ & 0.028 & 0.719 & 0.475 & \multirow{4}{*}{0.972} & $\begin{array}{l}\text { No Signifcant } \\
\text { Effect }\end{array}$ \\
\hline $\mathrm{X} 2 \rightarrow \mathrm{Y}$ & -0.088 & -2.143 & 0.037 & & Negative Effect \\
\hline $\mathrm{X} 3 \rightarrow \mathrm{Y}$ & 0.779 & 18.149 & 0.000 & & Positive Effect \\
\hline $\mathrm{X} 4 \rightarrow \mathrm{Y}$ & 0.198 & 5.482 & 0.000 & & Positive Effect \\
\hline \multicolumn{6}{|c|}{ Substructure $2(\mathrm{X} 1, \mathrm{X} 2, \mathrm{X} 3, \mathrm{X} 4$ to $\mathrm{Z})$} \\
\hline $\mathrm{X} 1 \rightarrow \mathrm{Z}$ & -0.062 & -3.006 & 0.004 & \multirow{5}{*}{0.992} & Negatif Effect \\
\hline $\mathrm{X} 2 \rightarrow \mathrm{Z}$ & 0.138 & 5.968 & 0.000 & & Positive Effect \\
\hline $\mathrm{X} 3 \rightarrow \mathrm{Z}$ & - & - & - & & - \\
\hline $\mathrm{X} 4 \rightarrow \mathrm{Z}$ & -0.054 & -2.444 & 0.018 & & Negatif Effect \\
\hline $\mathrm{Y} \rightarrow \mathrm{Z}$ & 1.103 & 39.265 & 0.000 & & Positive Effect \\
\hline
\end{tabular}

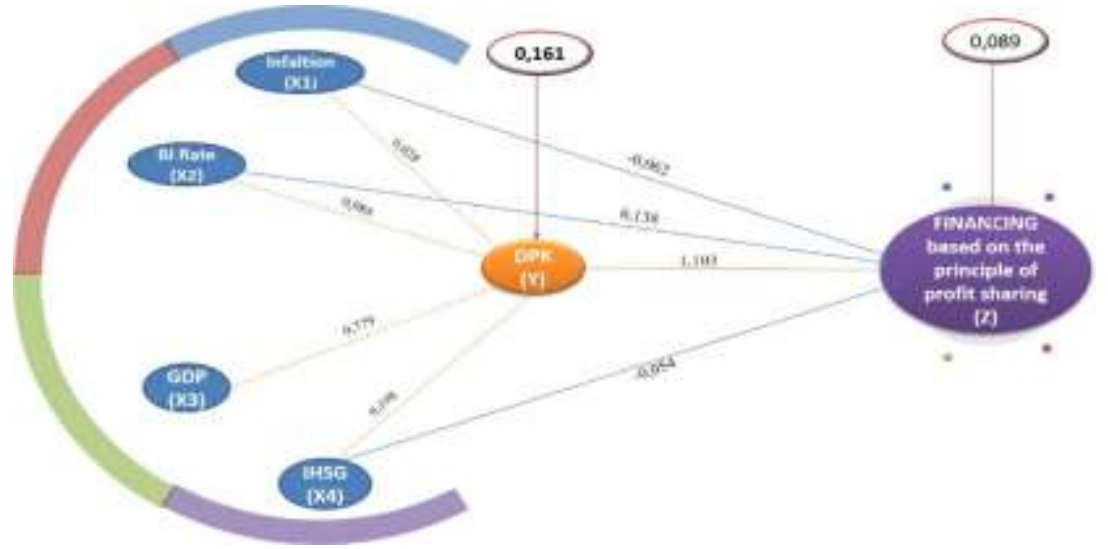

Source: Data Processed, 2020

Table 8. Summary of Model Parameters 
Table 9 Direct Effect and Indirect Effect Influence

\begin{tabular}{|c|c|c|c|c|}
\hline Variable & Direct & Indirect & Criteria & $\begin{array}{c}\text { The } \\
\text { Conclusion }\end{array}$ \\
\hline $\begin{array}{l}\text { Inflation } \\
\text { (X1) }\end{array}$ & -0.062 & $0.028 \times 1.103=0.030$ & $\begin{array}{l}\text { Direct } \\
\text { Effect < } \\
\text { Indirect } \\
\text { Effect }\end{array}$ & $\begin{array}{l}\text { The Parties } \\
\text { Fund are an } \\
\text { Intervening } \\
\text { Variable }\end{array}$ \\
\hline $\begin{array}{l}\text { BI Rate } \\
\text { (X2) }\end{array}$ & 0.138 & $-0.088 \times 1.103=-0.098$ & $\begin{array}{l}\text { Direct } \\
\text { Effect > } \\
\text { Indirect } \\
\text { Effect }\end{array}$ & $\begin{array}{l}\text { The Parties } \\
\text { Fund are not } \\
\text { an } \\
\text { Intervening } \\
\text { Variable }\end{array}$ \\
\hline GDP (X3) & - & $0.779 \times 1.103=0.859$ & - & - \\
\hline IHSG (X4) & -0.054 & $0.198 \times 1.103=0.218$ & $\begin{array}{l}\text { Direct } \\
\text { Effect < } \\
\text { Indirect } \\
\text { Effect }\end{array}$ & $\begin{array}{l}\text { The Parties } \\
\text { Fund are an } \\
\text { Intervening } \\
\text { Variable }\end{array}$ \\
\hline
\end{tabular}

Source: Data Processed, 2020

\subsection{RESEARCH DISCUSSION}

\subsubsection{Macroeconomic influences on Third Parties Fund}

The variable of Inflation, bank Indonesai Rate, GDP and IHSG simultaneously have a significant effect on the Third Parties Fund in Islamic Banking in Indonesia.

1.1 The effect of inflation on Third Parties Funds

The research findings show that inflation has no effect on third Parties Fund. These results are not in accordance with the theory that inflation will reduce a person's desire to save so that funds sourced from the community will decrease. This is because inflation can cause a decrease in people's real income due to a decrease in the value of real money. These findings also indicate that the inflation factor does not pay much attention to the public's decision to place funds in Islamic banking because there are other factors that influence public decisions so that the effect of inflation is not significant for third parties in Indonesia. This research is in line with the research of Sutono \& Batista Sufa Kefi (2013).

1.2 The effect of Bank Indonesia Rate on Third Parties Funds

The results of this study, it is known that the BI Rate has a negative and significant effect on TPF. This means that if the BI Rate increases, the THIRD PARTIES FUND will decrease, and vice versa. This is in accordance with research conducted by Friska Julianti (2013), the results of her research show that the BI Rate has a negative and significant effect on mudharabah savings. An increase in the BI Rate as the reference rate for conventional banks will have an impact on the performance of Islamic banks. Because the increase in the BI Rate will affect the interest rate followed by an increase in 
deposit and loan interest rates at conventional banks, so that people will be more likely to save their funds in conventional banks than in Islamic banks.

In addition, these findings also indicate that Islamic banking is still very vulnerable to the risk of the interest rate (BI Rate), which is the reference for conventional banking to attract public interest. In its operational mechanism, it is known that on the one hand, Islamic banks also carry out fundraising in the same way as commercial banks in the form of demand deposits, savings and time deposits. But on the other hand, the rewards that a sharia bank can give to its customers really depend on the income obtained from managing funds from collecting funds channeled back to customers through financing. So ideally, customers cannot expect a definite income as if they had deposited their funds in conventional banks. This is makes Islamic banks different from conventional banks. This phenomenon eventually led to the terms spiritual customer and rational customer, in which spiritual customers are considered to have higher loyalty to Islamic banks than rational customers who are profit oriented.

1.3 The effect of GDP on Third Parties Funds

GDP has a positive and significant effect on TPF, meaning that there is an increase in GDP, the TPF will also increase, and vice versa. This is in accordance with 2 previous studies by Ahmad Denny Mardiansyah (2004) and Ari Cahyono (2009). From these results it is known that GDP has a positive and significant effect on TPF. The increase in GDP is a reflection of increasing domestic production activities. In this condition, the community as the owner of the factors of production will agree to get a bigger income. This shows that when people's income increases, they will have a larger excess of funds after deducting their consumption so that more funds can be allocated for savings in Islamic banks. This positive and significant influence also indicates that the public prefers to place their funds in Islamic banking which is engaged in other sectors (the real sector and the capital market) as well as placing their funds in conventional banks.

1.3 The effect of IHSG on Third Parties Funds

IHSG has a significant effect on Third Parties Fund in Islamic banking in Indonesia. If the IHSG increases, the yield on bank deposits will be unattractive, as a result, third parties will experience a decline. When stock prices rise (increase in the IHSG), investment in the capital market will provide more attractive returns compared to investments in the form of savings and other bank deposits. As a result, people will shift their investment to the capital market.

If the IHSG goes down, the unbalanced bank will be more attractive, because it will experience an increase. When stock prices fall (evidence of a decline in the IHSG), investment in the capital market will provide an unattractive return compared to investment in the form of savings and other bank deposits. Especially considering the greater risk in the capital market compared to bank deposits guaranteed by the government. As a result, people will shift their investment to bank deposits. This is in accordance to Ari Cahyono (2009) 
4.4.2 Effect of Macroeconomics and Third Parties Fund on the Principle Financing of profit sharing

The Bank Indonesia Rate, Inflation, IHSG and Third Parties Fund variables simultaneously have a significant effect on financing based on profit sharing principles in Islamic Banking in Indonesia.

1.1 The effect of inflation on profit sharing financing

The results showed that inflation has a negative effect on financing based on the profit sharing principle. This means that if inflation increases, financing based on the profit sharing principle will decrease, and vice versa. This result is different from the research conducted by Ari Cahyono (2009), where inflation has a positive effect on financing. It is known that inflation is one of the macro variable instruments which greatly affects interest rates. If inflation increases, it will usually be followed by an increase in interest rates for both savings and financing.

1.2 The effect of Bank Indonesia Rate on profit sharing financing

The BI Rate has a positive and significant effect on financing based on the profit sharing principle. This means that if there is an increase in the BI rate, financing will also increase, and vice versa. Any increase in the BI Rate as the reference rate for conventional banks will have an impact on the performance of Islamic banks. Because the increase in the BI Rate will affect the interest rate followed by an increase in deposit and loan interest rates at conventional banks. The increase in loan interest rates will of course cause people to be reluctant to borrow from conventional banks due to the relatively high interest rates, so that people will be more likely to switch to Islamic banks where financing is more based on profit sharing.

\subsection{The effect of IHSG on profit sharing financing}

The results of the study found that the IHSG has a negative effect on profit sharing financing. In this case, the ups and downs of share prices do not have an impact on the profit sharing financing of Islamic banking because profit sharing financing is determined by third Parties Fund, interest rates and other factors.

\subsection{The effect of Third Parties Fund on profit sharing financing}

From partial test results, it is known that Third Parties Fund has a positive and significant influence on profit sharing financing. That is, if there is an increase in deposits, the financing will also increase. This result is supported by research conducted by Achmad Tohari (2010) . In normal conditions, financing is very dependent on the amount of available funds, both from the owner in the form of capital and from public funds (Third Parties Fund). That is, the greater the funding of a bank, the greater the potential of the bank concerned in the provision of financing. 


\subsubsection{Effect Of Macroeconomics On Profit Sharing Financing With Third} Parties Fund As Intervening Variable

\subsection{The effect of Infation On Profit Sharing Financing With Third Parties} Fund As Intervening Variable

The research findings show that inflation has significant effect on profit sharing financing with Third Parties Fund As Intervening Variable. If inflation rises, the people's purchasing power will decrease. People, especially low-income groups, will reduce the consumption they do. This tends to make people save their money in Islamic banks. This situation causes the bank's third Parties Fund to rise. This increase was followed by financing in Islamic banks which will also increase. If inflation decrease, the people's purchasing power will increase. The quantity of goods or services commonly used will be obtained at a lower price. This encourages people to consume more, this makes people withdraw their money from the bank so that third Parties Fund in the bank decrease. this tends to make Islamic banks reduce the portion of profit sharing financing

\subsection{The effect of BI Rate On Profit Sharing Financing With Third Parties} Fund As Intervening Variable

The research findings show that BI Rate has no significant effect on profit sharing financing with Third Parties Fund As Intervening Variable. The effect Bank Indonesia Rate has a better effect rather than the indirect effect trought third parties fund. In determining the rate of Islamic financing is using the going rate pricing method, which uses market interest rates as a reference. This happens, because in reality Islamic banks also compete with conventional banks to get customers who are rational customers. Floating customer behavior is strongly influenced by the level of convenience and the profitability of the returns obtained.The results showed inflation has no influence on financing based on the principle of profit sharing. This means that if inflation increases, financing based on the principle of profit sharing will decrease, and vice versa. This result is different from research conducted by Ari Cahyono (2009).

1.3 The effect of IHSG On Profit Sharing Financing With Third Parties Fund As Intervening Variable

The research findings show that IHSG has significant effect on profit sharing financing with Third Parties Fund As Intervening Variable. IHSG is directly negative while the intervening variable results have a significant positive effect, the better conclusion is when IHSG through Third Parties Fund for profit sharing financing because if the IHSG increases, then this is a picture of increasing economic growth, consequently experiencing an increase. When stock prices rise (increase in the IHSG), it indicates that the company is experiencing growth. To finance this growth, companies can use several sources of funds, namely: internal (company profit) and external: investors (in the form of capital) and creditors (in the form of loans). Banks are a source of external creditor funds that are commonly used by companies 
to fund investment and fulfill working capital loans. When the IHSG rose in general, the distribution of financing would increase.

\section{CONCLUSION}

The results of the study can be concluded that simultaneous testing of Macroeconomics (Inflation, Bank Indonesia Interest Rates, Real GDP, and IHSG) has an effect on Third Parties Fund. Whereas partially the Bank Indonesia Interest Rate variable, real GDP variable, IHSG variable partially affect Third Parties Fund where only the Inflation variable does not have a partial effect on Third Parties Funds, this shows the magnitude of the economic influence on Third Parties Fund both partially and simultaneously will bring the impact on the fluctuation of TPF causes sharing of financing to depend on the high or low of the Third Parties Fund.

The results of macroeconomic testing on financing, namely Simultaneous Testing, show that Macroeconomics (Inflation, Bank Indonesia Interest Rates, IHSG) and Third Parties Funds have an effect on Revenue Sharing. Meanwhile, the partial test shows that the inflation variable, BI Rate, IHSG and Third Parties Funds have a partial effect on financing using the profit sharing principle. where this shows that macroeconomics and Third Parties Fund on profit sharing financing have a considerable influence with indications of both positive and negative influences where this determines the rise or fall of profit sharing financing in Islamic banking. Meanwhile, if viewed from the direct effect or indirect effect which is better, then indirect the macroeconomics through Third Parties Fund is better for profit sharing financing, because the ups and downs of the Third Parties Fund due to macroeconomic effects will indirectly affect the profit sharing financing in Islamic banking.

The suggestions related to the results of this study are:

1. For the government, through policies it is expected to be able to maintain macroeconomic stability, which is to stabilize inflation and the Bank Indonesia Rate so that it does not fluctuate, continue to increase the people's real GDP income every year and maintain the composite stock price index (IHSG) so that it can more competitive and issuing clearer regulations related to Macroeconomic policies and synergy between banks, regulators and the public.

2. For further research, it should be able to add to the research sample and span of research years, so that it has more observation points and more reflects the real situation. Need to add other Macroeconomic variables and are expected to use a mixture (qualitative and quantitative)

3. For investors and banks as a material consideration to get profit, benefit and build a good image in the community for sustainable Islamic banking in the future. 


\section{BIBLIOGRAPHY}

Andraeny, D. (2011). Analisis Pengaruh Dana Pihak Ketiga, Tingkat Bagi Hasil Dan Non Performing Financing Terhadap Volume Pembiayaan Berbasis Bagi Hasil Pada Perbankan Syariah Di Indonesia (the Simposium Nasional Akuntansi XIV.). Jakarta.

Annisa, L. N., \& Yaya, R. (2015). Pengaruh Dana Pihak Ketiga, Tingkat Bagi Hasil Dan Non Performing Financing Terhadap Volume Dan Porsi Pembiayaan Berbasis Bagi Hasil Pada Perbankan Syariah Di Indonesia. Share: Jurnal Ekonommi Dan Keuangan Islam, 4(1).

Asutay, M. (2012). Aspirations of Islamic Moral Economy vs the Realities of Islamic Finance. Asian and African Area Studies, 11(2), 93-113.

Bank Indonesia. (2018a). Penjelasan BI 7-day (Reverse) Repo Rate.

Bank Indonesia. (2018b). Penjelasan Operasi Moneter.

Cahyono, A. (2009). Pengaruh Indikator Makroekonomi Terhadap Dana Pihak Ketiga dan Pembiayaan Bank Syariah Mandiri. Universitas Indonesia. Universitas Indonesia.

Heryanto, I., \& Wibowo, T. (2018). Path Analysis Menggunakan SPSS. Bandung: Informatika.

Huda, N. et. al. (2009). Ekonomi Makro Islam: Pendekatan Teoritis. Jakarta: Kencana.

Huey-Yeh Lin, \& Koo, N. H. F. M. (2016). The Impact of Macroeconomic Factors on Credit Risk in Conventional Banks and Islamic Banks: Evidence from Indonesia. International Journal of Financial Research, $7(4)$.

Juhro, S. M., Darsono, Syarifuddin, F., \& Sakti, A. (2018). Kebijakan Moneter Syariah dalam Sistem Keuangan Ganda: Teori dan Praktik. Jakarta: Tazkia Publishing.

Karim, A. A. (2017). Ekonomi Makro Islam. Jakarta: Rajagrafindo persada.

Kasmir. (2010). Pengantar Manajemen Keuangan. Jakarta: Kencana Prenada media Grup.

Kasmir. (2016). Dasar-Dasar Perbankan. Jakarta: Raja Grafindo Persada.

Kay, V. P. (2015). Gabungan Dan Variabel Ekonomi Makro Yang Mempengaruhinya Di Kota Ambon. Cita Ekonomika: Jurnal Ekonomi, $\operatorname{VII}(1)$.

Kuncoro. (2002). Manajemen Perbankan, Teori dan Aplikasi. Jakarta: Indeks Kelompok Gramedia.

Mankiw, N. G. (2018). Pengantar Ekonomi Makro (Edisi 7). Jakarta: Salemba Empat. 
Martalena, \& Malinda. (2011). Pengantar Pasar Modal (Edisi I). Yogyakarta: Andi.

Rivai, V. et. al. (2007). Bank \& Financial Institution Managemen Conventional \& Sharia System. Jakarta: Raja Grafindo Persada.

Saekhu. (2017). Dampak Indikator Makroekonomi terhadap Dana Pihak Ketiga Perbankan Syariah. Economica: Jurnal Ekonomi Islam, 8(1), 103-130.

Sinungan, M. (2003). Produktifitas Apa dan Bagaimana. Jakarta: Bumi Aksara.

Sopiana, H. (2012). Analisis Pengaruh Suku Bunga SBI dan Inflasi terhadap Penghimpunan Dana Pihak Ketiga (DPK) Perbankan di Indonesia. Journal of Economic \& Development, 10(1), 12 - 30.

Supriadi, E. (2014). SPSS+Amos. Jakarta: In Media.

Sutono, \& Batista Sufa Kefi. (2013). Pengaruh Faktor Makro Ekonomi Terhadap Penghimpunan Dana Pada Bank Umum Di Indonesia. Jurnal Ekonomi Manajemen Akuntansi, 20(34).

Syafi'i, A. (2017). Bank Syari'ah dari Teori ke Praktek (Cetakan Ke). Jakarta: Gema Insani Press. 
